\author{
Dr. sc. Nataša Zunić Kovačević, izvanredna profesorica \\ Pravnog fakulteta u Rijeci
}

\title{
UPRAVNOSUDSKA KONTROLA U POREZNIM STVARIMA
}

\author{
UDK: $349.9(497.5)$ \\ Izvorni znanstveni rad \\ Primljeno: 15. IX. 2015.
}

\begin{abstract}
Polazeći od aktualnog uređenja upravnosudske kontrole u poreznim stvarima, u radu se, nakon kratkog prikaza normativnopravnog okvira kontrole u poreznim stvarima, daje prikaz određenih pokazatelja provedbe upravne i upravnosudske kontrole u poreznim stvarima. Iskustva primjene upravne kontrole u poreznim stvarima i analiza dostupnih pokazatelja recentne upravnosudske kontrole u poreznim stvarima povod su traženju novih rješenja učinkovitije zaštite prava poreznih obveznika, ali i ostvarenja zadaća poreznih tijela. Promjene poreznih sustava koje se događaju u okruženju imaju učinke i na hrvatski poreznopravni okvir pa se u radu razmatraju mogući pravci razvoja i ustrojavanja alternativnih oblika rješavanja sporova u području oporezivanja. Za prikaz mogućeg razvoja kontrolnih mehanizama u poreznom pravu odabrana je uspostava arbitražnog pravosudnog sustava u poreznim stvarima. Kontekst pojavljivanja alternativnih oblika rješavanja sporova u poreznim stvarima nameće pitanje jesu li promjene u provedbi kontrole u poreznim stvarima evolucijske naravi.
\end{abstract}

Ključne riječi: upravnosudska kontrola, porezne stvari, upravni spor, alternativni oblici rješavanja sporova u poreznim stvarima, arbitražni pravosudni sustav

\section{UVODNO RAZMATRANJE}

Ustavom Republike Hrvatske građanima su zajamčene sigurnost i zaštita od prekomjernog i nezakonitog posezanja porezne uprave, kao dijela uprave, u njihova prava. Navedena zaštita zajamčena je prije svega kroz kontrolu zakonitosti poreznih akata, koja je u nadležnosti upravnih sudova. Upravni sudovi i upravni spor svojevrsno su jamstvo zakonitosti postupanja poreznih tijela, kako onih u prvom stupnju, tako i drugostupanjskog tijela. Kako suvremena kretanja u području oporezivanja ukazuju na promjenu odnosa izvršne vlasti, u kontekstu problematizirane tematike, porezne vlasti i građana kao porezenih obveznika, iz odnosa pune nadređenosti u odnos suradnje, to je za očekivati, iako ne isključivo iz tog razloga, i moguće promjene u ostvarivanju zaštite prava poreznih obveznika te instrumentariju i mehanizmima kontrole u poreznim stvarima. U toj se „lepezi“ mogućih i novih putova zaštite prava poreznih obveznika mogu pojaviti različiti modeli i vrste zaštite, no u radu se daje kratki prikaz svojevrsne alternative upravnosudskoj kontroli, u obliku porezne sudske arbitraže. Uvodno se, za potrebe pisanja rada, pojašnjava poimanje pojma iz naslova rada ,poreznih stvari“ na način da se za potrebe predmetnog rada taj pojam restriktivno shvaća te podrazumijevaju prije svega poreznopravne odnose i porezne akte kao upravne akte državne uprave, u pogledu kojih je osigurana i zajamčena sudska zaštita, a u 
povodu kojih nastaje spor.

\section{NORMATIVNI OKVIR UPRAVNOSUDSKOG NADZORA U POREZNIM STVARIMA}

Ustavom je Republike Hrvatske utvrđeno načelo da pojedinačni upravni akti državne uprave i tijela koja imaju javne ovlasti moraju biti utemeljeni na zakonu te se jamči sudska kontrola zakonitosti tih akata. ${ }^{1}$ Zakon o Poreznoj upravi propisuje da je porezna upravna organizacija u sastavu Ministarstva financija čija je temeljna zadaća primjena i nadzor primjene poreznih propisa i propisa o prikupljanju doprinosa. ${ }^{2}$ Nadzor primjene poreznih propisa citiranom normom također je stavljen u nadležnost same upravne organizacije, pri čemu porezna uprava provodi unutarnji nadzor nad zakonitošću rada i pravilnom primjenom propisa iz svoje nadležnosti $\mathrm{s}$ namjerom otklanjanja utvrđenih nepravilnosti te ujednačavanja prakse rada. ${ }^{3}$ Kada je riječ o o unutarnjoj kontroli, porezna uprava takvu kontrolu provodi s namjerom otkrivanja, utvrđivanja i sprečavanja kršenja zakonitosti rada i pravila službe od strane službenika. ${ }^{4}$ Ministar financija pravilnikom je propisao način provođenja unutarnjeg nadzora i unutarnje kontrole. ${ }^{5}$ Unutarnji je nadzor definiran kao skup radnji, metoda i postupaka koje provodi porezna uprava radi nadziranja zakonitosti svoga rada i pravilne primjene propisa iz svoje nadležnosti s namjerom otklanjanja utvrđenih nepravilnosti te ujednačavanja prakse rada. U radu se ne problematiziraju svi oblici sudske kontrole u poreznim stvarima, već je fokus na restriktivno shvaćenom pojmu poreznih stvari u smislu poreznopravnih odnosa i sporova u povodu istih. Stoga zadaća porezne uprave nadzora i kontrole, koja je uređena citiranim propisom, nije predmetom razmatranja.

Temeljni propis koji uređuje poreznopravne odnose, Opći porezni zakon, propisuje da porezni akt kojim se odlučuje o pojedinačnim pravima i obvezama iz porezno-pravnog odnosa jest porezno rješenje, a sukladno posebnim propisima može imati i drugi naziv. ${ }^{6}$ Uređujući pitanje pravne zaštite poreznih obveznika, OPZ je propisao da se protiv poreznog akta kojim je odlučeno o pojedinačnim pravima i obvezama iz porezno-pravnog odnosa može podnijeti žalba nadležnom

1 Ustav Republike Hrvatske, Narodne novine 56/1990., 135/1997., 113/2000., 28/2001., 76/2010., 5/2014. (dalje u tekstu: Ustav), v. čl. 19.

2 Zakon o Poreznoj upravi, Narodne novine 148/2013. i 141/2014., (dalje u tekstu: ZPU), v. čl. 2., st. 1.

3 V. ZPU, čl. 75., st. 1.

4 V. ZPU, čl. 75., st. 2. Važno je ukazati da u radu ne slijedimo terminologiju zakona, jer se u radu pojmovi nadzora i kontrole koriste kao sinonimi. 95/2014.

5 Pravilnik o provođenju unutarnjeg nadzora i unutarnje kontrole u Poreznoj upravi, Narodne novine

6 Opći porezni zakon, Narodne novine 147/2008., 18/2011., 78/2012., 136/2012., 73/2013. i 26/2015. (dalje u tekstu: OPZ). Porezni akt jest svaki akt kojim se pokreće, dopunjuje, mijenja ili dovršava neka radnja u poreznom postupku. Vidi, čl. 49., st. 1. i 3. OPZ-a. 
drugostupanjskom poreznom tijelu. ${ }^{7}$ Riječ je o Samostalnom sektoru za drugostupanjski upravni postupak koji je ustrojstvena jedinica Ministarstva financija. U okviru svojih širokih nadležnosti, ${ }^{8}$ ova ustrojstvena jedinica Ministarstva financija rješava o žalbama protiv upravnih akata porezne uprave, i upravnih akata upravnih tijela županija i velikih gradova propisanih posebnim zakonima, rješava o žalbama protiv upravnih akata ustrojstvenih jedinica Ministarstva, provodi postupak povodom izvanrednih pravnih lijekova; donosi rješenja u provedbi upravnog nadzora nad zakonitošću upravnih akata porezne uprave te daje odgovore na tužbe povodom pokrenutih upravnih sporova i zastupa Ministarstvo pred upravnim sudovima povodom pokrenutih upravnih sporova protiv upravnih akata iz djelokruga Samostalnog sektora za drugostupanjski upravni postupak.

OPZ uređuje pravo poreznog obveznika na sudsku zaštitu na način da propisuje da se potiv rješenja kojim je odlučeno o žalbi može podnijeti tužba nadležnom sudu. ${ }^{9}$

U svezi sa sudskom zaštitom prava poreznih obveznika valja spomenuti da OPZ uređuje izvanredni pravni lijek koji se može primjenjivati samo u poreznim stvarima. Riječ je o mijenjanju i poništavanju poreznog rješenja u vezi $\mathrm{s}$ upravnim sporom. Sukladno čl. 171. OPZ-a, porezno tijelo protiv čijeg je rješenja pravodobno podnesena tužba nadležnom sudu može do okončanja spora poništiti ili izmijeniti svoje rješenje iz onih razloga iz kojih bi sud mogao poništiti to rješenje. Poništavanje ili izmjena rješenja u tom se slučaju može izvršiti samo ako se na taj način otklanja nezakonitost rješenja i ako se time porezni obveznik ne dovodi u lošiji položaj. Rješenje se mijenja ili poništava samo sukladno tužbenom zahjevu, a ne može se ovaj pravni lijek primijeniti niti pri djelomičnom usvajanju tužbenog zahtjeva jer se time svrha instituta ne bi ostvarila: izbjegavanje već pokrenutog sudskog poništavanja rješenja iz razloga ekonomičnosti postupka. ${ }^{10}$

Zakonom o upravnim sporovima propisano je da u upravnim sporovima

7 Žalba se može podnijeti i onda kada žalitelj istakne kako o njegovu zahtjevu za donošenje poreznog akta nije donesena odluka u propisanom roku. OPZ, čl. 159., st. 1. i 2. i čl. 164. O žalbi protiv poreznog akta koji je donijelo prvostupanjsko porezno tijelo odlučuje nadležno drugostupanjsko porezno tijelo određeno zakonom.

8 Pored navedenoga, postupa po podnescima u neupravnim predmetima; surađuje u pripremi nacrta prijedloga zakona i međunarodnih ugovora iz područja poreza i carina te u pripremi stručnih uputa radi jedinstvenog postupanja u upravnom postupku; prati primjenu poreznih i carinskih propisa te inicira njihovu izmjenu; sustavno prati međunarodne ugovore sklopljene u području poreza i carina; prati europske smjernice u postupcima oporezivanja i carinjenja, prati i analizira sudsku praksu Europskog suda. U Samostalnom sektoru za drugostupanjski upravni postupak, ustrojene su tri službe: Služba za drugostupanjski porezni postupak i zastupanje, Služba za drugostupanjski postupak u predmetima carina, trošarina, koncesija, predstečajnih nagodbi i zastupanje i Služba za drugostupanjski postupak u poreznim nadzorima i zastupanje. U Službi za drugostupanjski porezni postupak i zastupanje ustrojena su tri odjela: Odjel za poreze, doprinose i ovrhu, Odjel za porez na promet nekretnina te Odjel za lokalne poreze i prekogranično oporezivanje. Vidi Uredbu o unutarnjem ustrojstvu Ministarstva financija, Narodne novine 32/2012., 67/2012., 124/2012., 78/2013., 102/2013., 24/2014., 134/2014. i 154/2014.

9 V. OPZ, čl. 159., st. 3.

10 V. OPZ, čl. 171. 
upravni sudovi odlučuju o zakonitosti odluka javnopravnih tijela o pravima, obvezama i pravnim interesima fizičkih i pravnih osoba i drugih stranaka te o zakonitosti postupanja javnopravnih tijela iz područja upravnog prava, s ciljem osiguranja zakonitosti i sudske zaštite prava i pravnih interesa fizičkih i pravnih

osoba i drugih stranaka povrijeđenih pojedinačnim odlukama ili postupanjem javnopravnih tijela. ${ }^{11}$

ZUS uređuje da je predmet upravnog spora ocjena zakonitosti pojedinačne odluke kojom je javnopravno tijelo odlučilo o pravu, obvezi ili pravnom interesu stranke u upravnoj stvari (upravnim aktom) protiv koje nije dopušteno izjaviti redoviti pravni lijek; ocjena zakonitosti postupanja javnopravnog tijela iz područja upravnog prava kojim je povrijeđeno pravo, obveza ili pravni interes stranke protiv kojeg nije dopušteno izjaviti redoviti pravni lijek; ocjena zakonitosti propuštanja javnopravnog tijela iz područja upravnog prava da u zakonom propisanom roku odluči o pravu, obvezi ili pravnom interesu ili redovitom pravnom lijeku stranke odnosno da postupi prema propisu. ${ }^{12}$

Provodeći sudsku kontrolu upravnim sporom, upravni sudovi osiguravaju zakonitost rada poreznih tijela u poreznom postupku koja se manifestira prije svega u zakonitosti poreznih akata kojima se odlučuje o pojedinačnim pravima i obvezama građana kao poreznih obveznika. Porezni obveznici, dakle, imaju pravo pokrenuti upravni spor kada smatraju da im je poreznim aktom protiv kojega nije dopušteno izjaviti redovni pravni lijek povrijeđeno pravo ili interes zasnovan na zakonu, odnosno ako se u postupku nije poštovalo nečelo zakonitosti te zbog tzv. šutnje administracije.

Osiguravajući zakonitost upravnog akta, upravni sud u upravnom sporu osigurava zaštitu prava i pravnih interesa poreznih obveznika, ovdje najčešće i tužielja, što mu pripadaju temeljem pravnih propisa na temelju kojih se rješavalo u poreznom postupku. Upravne sporove rješavaju upravni sudovi i Visoki upravni sud Republike Hrvatske. Upravni sudovi odlučuju o tužbama protiv pojedinačnih odluka poreznih tijela, protiv postupanja poreznih tijela, protiv upravnih ugovora, propuštanja donošenja pojedinačne odluke ili postupanja u roku te drugim zakonom propisanim slučajevima, a Visoki upravni sud odlučuje o žalbama protiv presuda upravnih sudova i rješenja protiv kojih nije dopuštena žalba, o sukobu nadležnosti upravnih sudova i drugim zakonom propisanim slučajevima. ${ }^{13}$

11 Zakon o upravnim sporovima, Narodne novine 20/2010., 143/2012. i 152/2014. (dalje u tekstu: ZUS). V. ZUS, čl. 1 i 2.

12 ZUS u čl. 4. uređuje da se upravni spor ne može voditi: u stvarima u kojima je sudska zaštita osigurana izvan upravnog spora i o pravilnosti pojedinačne odluke donesene primjenom slobodne ocjene javnopravnog tijela, ali se može voditi o zakonitosti takve odluke, granicama ovlasti i svrsi radi koje je ovlast dana; protiv postupovne odluke javnopravnog tijela, već se takva odluka može pobijati tužbom protiv odluke o glavnoj stvari, ako zakonom nije drukčije propisano.

13 V. ZUS, posebno čl. 12. 


\section{NEKI POKAZATELJI PROVEDBE UPRAVNOSUDSKE KONTROLE U POREZNIM STVARIMA}

Sukladno supra navedenome, do upravnosudske kontrole u poreznim stvarima dolazi najčešće u povodu ostvarenja prava poreznog obveznika na sudsku zaštitu nakon donošenja rješenja kojim je odlučeno o žalbi.

$\mathrm{U}$ analizi navedenoga, korisno je i zanimljivo istaknuti dobivene podatke od Samostalnog sektora za drugostupanjski upravni postupak. Naime, 2012. godine, od 19.034 riješenih žalbi, čak 16.068 ih je odbijeno odnosno $84 \%$ (svega 13 odbačenih), dok je svega 2.953 (15 \%) žalbi uvaženo. U 2013. godini udio odbačenih žalbi gotovo se i ne mijenja, doduše raste: od 17.346 riješenih žalbi, njih je 15.617 odbijeno (90 \%), a svega 1.703 uvaženo (9 \%). U 2014. godini nastavlja se takav razmjer, odnosno od 10.413 riješenih žalbi čak je 8.750 odbijenih žalbi (84 \%), a 1.653 su uvažene žalbe (15\%). Dakle, u promatranom razdoblju je od riješenih 46.793 žalbi njih 40.435 odbijeno (86 \%), a svega $13 \%$ odnosno 6.309 jesu uvažene žalbe. ${ }^{14}$

Postupak pred drugostupanjskim tijelom u prosjeku traje čak 2,5 godine. ${ }^{15}$

Iako je moguće već i ovdje otvoriti pitanje opravdanosti i izbora osiguranja ovog vida zaštite prava poreznih obveznika (pitanje je treba li razmisliti o isključenju drugog stupnja upravnog odlučivanja i postupanja u poreznom postupku odnosno poreznim stvarima, odnosno „,premjestiti nadležnost“ s upravno-izvršne na sudsku vlast),${ }^{16}$ navedeno će biti amplius infra objašnjeno, u mjeri koju dopuštaju

14 Podaci nisu objavljeni, dostavljeni autoru od strane Samostalnog sektora za drugostupanjski upravni postupak.

15 Isto, podaci dostavljeni na traženje autora.

16 Za potrebe rada potrebno je dati kratki pregled sličnosti i razlika između sudstva i javne uprave, odnosno njihovih funkcija u suvremenoj državi. I sudovi (u RH normativno određeni u čl. 2. Zakona o sudovima) i javnopravna tijela (u RH normativno određena u čl. 1. Zakona o općem upravnom postupku) ubrajaju se u širi pojam državnih organa (ili državnih tijela), koje možemo definirati kao „organizacijske jedinice države koje djeluju za državu realizirajući njezine ciljeve i zadaće i ne mogu se od nje odvojiti“ (Vuković, Đ., Pravna država, Zgombić \& Partneri, Zagreb, 2005., str. 3.). Vuković dalje navodi kako se ,državne funkcije, legislativna, upravna i sudska, ostvaruju putem posebnih organa, kao integralnih, ali i diferenciranih dijelova cjeline prilagođenih za pojedine vrste poslova (...) Državni organi ostvaruju svoje zadaće, koje su im date u nadležnost, putem fizičkih osoba kao službenih osoba“ (loc. cit.). Suština načela diobe državne vlasti, koje je prvi put sustavno oblikovao Montesquieu u epohalnom djelu ,O duhu zakona“ (Ženeva, 1748.), jest upravo u dodjeli različitih temeljnih državnih funkcija različitim tijelima (organima). Sokol ističe da kao kriterij određivanja i razlikovanja državnih funkcija valja potražiti zajednička načela djelovanja i obilježja akata državnih tijela u obavljanju poslova - bili oni istovrsni ili različiti - državne vlasti“" (Smerdel, B., Sokol, S., Ustavno pravo, Pravni fakultet, Zagreb, 2005., str. 312.). Ujedno se opredjeljuje za kvadrijalističko shvaćanje državnih funkcija, koje prepoznaje, uz zakondavnu, sudsku i upravnu, posebno i izvršnu funkciju (ibid, str. 313.). Možemo zaključiti kako u svim državama u kojima se ustavni model ustrojstva vlasti temelji na načelu diobe vlasti (vidi npr. čl. 4. Ustava RH), sudsku funkciju obavlja samostalno i neovisno sudstvo (isto i: čl. 117. Ustava RH), a upravnu funkciju tijela javne uprave. Teoretske kriterije razlikovanja upravne i sudske funkcije razvili su već Duguit i Jelinek, inzistirajući pritom na materijalno-funkcionalnim razlikama (detaljnije u: Borković, I., Upravno pravo, Narodne novine, Zagreb, 2002., str. 256.). Međutim, razvojem pravne države, prema Borkoviću, gubi se stvarna sadržajna razlika između uprave i sudstva. Prvo, nakon prihvaćanja načela zakonitosti uprave u užem smislu, uprava je postavljena $u$ isti odnos prema objektivnom pravnom poretku kao i druga državna tijela (prema: loc. cit.). Drugo, ,razvoj proceduralnog normiranja rezultirao je u mnogim zemljama 
tema i opseg ovoga rada. Porezni bi postupak, unatoč imanentnoj posebnosti i supspecijalnosti, morao biti uređen što je moguće jasnijim i preciznijim pravnim okvirom. Dapače, pojednostavljenje poreznog postupka, u smislu jasnoće, preciznosti i jednostavnosti reguliranja uz primjenu tri razine odlučivanja gdje je jedna u upravnom postupku pred upravnim tijelom, a dvije u upravnom sporu, predstavlja mjeru modernizacije javne uprave. ${ }^{17}$

Upravni spor i upravni sudovi predstavljaju svojevrsnog jamca zakonitosti postupanja poreznih tijela i to, kako onih u prvom stupnju, tako i drugostupanjskog tijela. Pitanje zadržavanja drugostupanjskog upravnog tijela kao dijela sustava pravne zaštite u poreznim stvarima zahtijevalo bi detaljniju raščlambu i analizu, no čini se da ga nameću gore prikazani brojčani pokazatelji upravne kontrole u poreznim stvarima, koju provodi navedeni sektor za drugostupanjski postupak.

Nužnost sudske kontrole uprave razvija se na način da se od početne ideje $\mathrm{i}$ težnje za učinkovitom sudskom kontrolom zakonitosti upravnih akata u suvremeno doba sve više govori o ljudskom pravu na upravno sudovanje, ${ }^{18}$ pa tako, u kontekstu oporezivanja, i na ljudska prava u području oporezivanja. Pravo poreznih obveznika na sudsku zaštitu i ostvarenje prava pred sudovima dio je brojnih poreznih povelja koje su donijele mnoga zakonodavstva kako europskih država, tako i šire.

Jamstvo sudske zašitite u poreznim stvarima jedan je od temelja vladavine prava. Pravna sigurnost imperativ je svih suvremenih država, za koje je odavno prepoznato kako su i porezne države. Dapače, neizbježnost poreza i njegova svepristunost u suvremenim društvima dominantno su obilježje svih zajednica. Istodobno, sve zajednice - suvremene države - kontinuirano ulažu napore kako bi se približile idealu pravne države. Pri tome porezi čine sastavni dio tih napora jer je potrebno ostvarenje porezne i pravne države u jednome.

Iz prikazane prakse, prije svega upravne kontrole u poreznim stvarima, proizlazi da porezni obveznici ne ostvaruju zaštitu svojih prava i zakonitosti od

propisivanjem i kodificiranjem načela upravnog postupanja (upravni postupak), u čemu se, i opet, uprava izjednačila sa sudstvom (...) Teško je, dakle, govoriti o nekoj stvarnoj materijalnoj - sadržajnoj razlici između uprave i sudstva, radije bi se moglo prihvatiti shvaćanje da postoji samo razlika formalno organizacijske prirode“ (ibid., str. 257.). Triva i Dika također naglašavaju razlike na „organizacijskom planu, naročito u pitanjima funkcionalne i organizacijske samostalnosti i međuzavisnosti sudskih i upravnih tijela“" (Triva, S., Dika, M., Građansko parnično procesno pravo, Narodne novine, Zagreb, 2004., str. 95.). S obzirom na to da se u Hrvatskoj, s nadzakonskom pravnom snagom, izravno primjenjuje i Europska konvencija za zaštitu ljudskih prava (MU br. 18/97, 6/99, 14/02, 13/03, 9/05, 1/06, 2/10; dalje: EKLJP), upućujemo i na praksu Europskog suda za ljudska prava, koja pruža odgovore na pitanje koja se tijela mogu smatrati sudom (tribunalom), u smislu primjene čl. 6. EKLJP-a, kojim se jamči pravo na pošteno suđenje. Pritom je naglasak na svojstvima tijela, a ne na njegovom formalnom statusu (detaljnije o ovome vidi: Uzelac, A., „Pravo na pravično suđenje u građanskim predmetima: Nova praksa Europskoga suda za ljudska prava i njen utjecaj na hrvatsko pravo i praksu“, Zbornik PFZ, vol. 60., br. 1., 2010., str. 110-112). Prema, Žunić Kovačević, N., Gadžo, S., „Institut zakonskog poreznog jamstva nakon novele općeg poreznog zakona 2012.: „proboj pravne osobnosti“ trgovačkih društava u slučaju zloporabe prava“, Zbornik Pravnog Fakulteta Sveučilišta u Rijeci, 34 (2013.), 1; 393-416.

17 Koprić, I., Europski standardi i modernizacija upravnog sudovanja u Hrvatskoj, Zagreb: Institut za javnu upravu, 2014., str. 12-34, dostupno na: https://www.academia.edu/12422481.

18 Koprić, op. cit. 
strane drugostupanjskoga upravnog tijela već opravdano očekuju istu ostvariti u sudskom postupku, kroz upravni spor.

Uzimajući u obzir gore navedeno te pravni okvir kontrole u poreznim stvarima kroz dvostupanjski porezni postupak, a potom i upravno sudovanje, indikativni su i određeni pokazatelji strukture rješavanja upravnosudskih postupaka u poreznim stvarima. Naime, iz analize dostupnih i dostavljenih podataka, ${ }^{19}$ na Upravnom sudu u Zagrebu je od 1. siječnja 2012. godine do 31. kolovoza 2015. godine zaprimljeno 17.737 predmeta, od čega je 3.611 zaprimljenih poreznih predmeta. Dakle, udio poreznih predmeta iznosi 20,35 \%. Na Upravnom sudu u Osijeku je u istom razdoblju ukupno zaprimljeno 5.807 predmeta, od kojih je 1.245 poreznih predmeta, što čini $21,43 \%$. U podudarnom je razdoblju ${ }^{20}$ kod Upravnog suda u Rijeci primljeno 6.630 predmeta, od čega 1.631 porezni predmet, odnosno $25 \%$. $\mathrm{Na}$ Upravnom sudu u Splitu u istom je razdoblju zaprimljeno 10.506 predmeta, od čega 2.244 poreznih predmeta, odnosno $21,35 \%$ u odnosu na ukupan broj zaprimljenih predmeta.

Na Visokom upravnom sudu RH u istom je razdoblju zaprimljeno 870 žalbi na odluke prvostupanjskih upravnih sudova iz porezne materije što je iznosilo 26,5 $\%$ u ukupnom broju zaprimljenih predmeta.

Na Upravnom su sudu u Zagrebu, u promatranome razdoblju, od 3.611 poreznih predmeta, u 678 predmeta tužbe uvažene, gdje se uključuju odluke kojima je tužba vraćena i predmet vraćen na ponovni postupak, ali i odluke u kojima je sud sam riješio stvar. Pred Upravnim sudom u Osijeku, u istom je periodu riješeno 1.087 poreznih predmeta s time da je u 137 predmeta poništen osporavani upravni akt $(12,60 \%$ predmeta), dok je u 113 predmeta poništen osporavani upravni akt i predmet vraćen tuženiku na ponovni postupak (10,39 \% predmeta).

$\mathrm{Na}$ Upravnom je sudu u Rijeci ${ }^{21}$ u 1.154 riješenih poreznih predmeta u 295 predmeta poništen akt i predmet vraćen na ponovni postupak, dakle $25 \%$. $^{22} \mathrm{U}$ istom razdoblju je na Upravnom sudu u Splitu donesena odluka u 1.324 porezna predmeta, od čega je u 542 predmeta poništen osporavani akt, što iznosi 40,93\% od ukupnog broja odluka donesenih u poreznim predmetima.

$\mathrm{Na}$ Visokom upravnom sudu $\mathrm{RH}$, u navedenom je razdoblju potvrđeno 328 prvostupanjskih odluka, odnosno 46,2 \%, a poništeno je 86 prvostupanjskih odluka $(12,1 \%)$ te poništeno s vraćanjem na ponovni potupak 6 prvostupanjskih odluka, odnosno $0,8 \%$.

19 Podaci su za potrebe projektne analize, ali i za pisanje rada, dobiveni iz pisarnica Visokog upravnog suda RH te Upravnih sudova u Osijeku, Rijeci, Splitu i Zagrebu.

20 Do 1. travnja 2015. godine.

21 Od ukupno riješenog 3931 predmeta, riješeno je 1154 poreznih predmeta, dakle $29 \%$ jest udio poreznih predmeta u ukupnom broju riješenih predmeta u tom razdoblju.

22 Pri tome je moguće uočiti da je meritorno riješeno u svega 31 predmetu (nekih $3 \%$ ). Vidi Pičuljan, Z., Britvić-Vetma, B., „Primjena i evolucija upavnog spora pune jurisdikcije“, Zbornik radova Pravnog fakulteta u Splitu, god. 47, 1/2010, str. 53-64, gdje autori navode da su za naš sustav upravnog spora tipični upravo upravni sporovi poništenja upravnih akata, dok su sporovi pune jurisdikcije „,netipični“, str. 58. 
U prosjeku trajanje postupka na Visokom upravnom sudu RH iznosi 2,1 godinu.

U prikazu brojčanih pokazatelja strukture rješavanja sporova, udio predmeta u kojima su tužbe uvažene najčešće uključuje odluke kojima je tužba vraćena i predmet vraćen na ponovni postupak i odluke u kojima je sud sam meritorno riješio stvar. Unatoč tome, iz nekih je podataka dijelom bilo moguće uočiti da udio meritorno riješenih predmeta od strane suda ima tendenciju rasta. Na žalost, riječ je i dalje o slaboj zastupljenosti takvih predmeta.

Naime, iz povijesne se perspektive može uočiti da je gotovo jedina svrha poreznog spora - upravnog spora bila kontrola odnosno ocjena zakonitosti poreznog akta dok je rješavanje o pravu odnosno obvezi izostajalo, makar je bilo moguće ili čak i obvezatno. Takav pristup poreznim predmetima u početku reforme hrvatskog upravnog sudovanja iz početka 2010. godine ostaje nepromijenjen. Pri tome se ispravno u znanstvenoj i stručnoj literaturi navodi da rješavanje poreznih predmeta kroz puku ocjenu zakonitosti poreznog akta ne samo da znači dulji i teži put do zakonite odluke, već istodobno stvara mogućnost da upravni sud odlučuje o istoj stvari više puta. Nema sumnje da su takvim pristupom i rješenjem upravni sudovi manje učinkoviti ${ }^{23}$ te preopterećeni poreznim predmetima, budući da uprava „propušta“ i prepušta sudovima da rješavaju složene predmete (umjesto nje). ${ }^{24}$ Upravno sudovanje često se svodi na upravni spor, no ipak treba ukazati na, danas dobro poznate, različite temeljne modele upravnog sudovanja, prema vrsti sudova koji nadziru upravu, pa i poreznu upravu: prvi, anglosaksonski model gdje kontrolu provode redoviti sudovi te drugi model gdje je to u rukama posebnih, upravnih sudova (francuski model). Naime, jasno je da razvoj društva stvara nove i mijenja postojeća pravila u društvenim zajednicama pa je novo reguliranje tih odnosa dovelo i do razvoja novih grana prava, pa posljedično nekada i novih modela sudovanja. Tako danas upravni spor obuhvaća velik broj pravnih područja. Takva je brojnost i raznolikost pravnih područja i pitanja koja iz njih izviru dovela do daljnje specijalizacije i razvoja posebnih upravnih sudova, poput financijskih sudova, poreznih sudova, radnih sudova i sl. Istodobno, taj je razvoj prisutan i predstavlja konstitutivni dio ili komponentu jednog „europskog procesa“ koji se i dansas događa a koji karakterizira kretanje prema zajedničkom europskom modelu upravnog sudstva. ${ }^{25} \mathrm{U}$ tom smislu, stvara se perspektiva ili čak zaključuje o neizbježnosti daljnjeg razvoja i ustrojavanja posebnih upravnih sudova pa i izvansudskih mehanizama rješavanja upravnih sporova.

Usprkos tome što je upravni spor u poreznim stvarima dugo vremena bio sveden na spor o zakonitosti upravnog akta (vidi supra), praksa pokazuje da se u novije vrijeme ipak primjenjuje u poreznim stvarima i spor pune jurisdikcije,

23 Ipak, neki autori ukazuju i na pozitivne strane takva uređenja, poput brzine i jeftinoće takva uređenja i postupanja. Vidi, tako, Kriletić, „Upravnoračunski spor“, Zbornik radova Pravnog fakulteta $u$ Splitu, god. 47, 1/2010., str. 149.

24 Prema Pičuljan, Britvić-Vetma, str. 59.

25 Prema Koprić, loc. cit. 
u kojem sud odlučuje o konkretnoj stvari i sam utvrđuje činjenično stanje. ${ }^{26}$ To je posebno značajno s obzirom na to da je upravo upravni spor pune jurisdikcije nadasve u skladu sa zajamčenom sudskom zaštitom prava poreznih obveznika.

S ciljem rasterećenja upravnih sudova i ostvarenja učinkovite pravne zaštite građana u poreznim stvarima, neophodno je promišljati i raditi na razvoju novih i dodatnih instrumenata ili mehanizama, ne samo sudskog, već i izvansudskog rješavanja poreznih sporova. ${ }^{27}$ Iako OPZ otvara mjesta nekim vidovima ugovaranja i sporazumijevanja još u fazi poreznog postupka, gdje se uz očuvanje zakonitosti ipak smanjuje potreba za upravnosudskom zaštitom, poznato je da Preporuka Vijeća Europe ${ }^{28}$ iz 2001. godine predlaže veći broj različitih instrumenata, poput koncilijacije, posredovanja, sporazumijevanja i arbitraže, s ciljem rasterećenja upravnog sudstva. ${ }^{29}$ Aktualna disfunkcionalnost u odnosima porezne vlasti i građana, poreznih obveznika, dodatni je razlog predlaganju drugačijeg sustava kontrole u poreznim stvarima. ${ }^{30}$

\section{KONTEKST POJAVLJIVANJA ALTERNATIVNIH OBLIKA RJEŠAVANJA SPOROVA U POREZNIM STVARIMA}

Promjena paradigmi ukazuje na kretanja u suvremenim društvima koja idu od koncepta koji se temelji na moći i pravu oporezivanja, što se pridaje vlasti, i utemeljen je na načelima i pravnim pravilima - ka jednom novom, intenzivnijem ili jačem i kvalitetnijem odnosu čiji temelji nisu u moći i sili već u korektnom ili fair-play-pristupu. Takav, novi, pristup proizlazi i iz svojevrsnog voluntarizma i dobrovoljnosti poreznih obveznika koji su mogući s obzirom na povjerenje koje imaju spram porezne vlasti, a uvodi se kroz lepezu raznih oblika neobvezujućih pravila, instrumente soft-lawa, preporuka i sl.

Paradigma koja se mijenja, temeljni pristup koji doživljava promjenu, zasnovani su na javnopravnom konceptu u kojemu se odnos poreznih obveznika i porezne administracije temelji na ostvarenju porezne moći ili vlasti nad oporezivanjem. Taj koncept proizlazi iz njemačke javnopravne doktrine iz 19. stoljeća, sukladno kojoj je to odnos u kojem se ostvaruje i realizira porezna vlast odnosno moć oporezivanja. Otuda shvaćanje da je plaćanje poreza obveza koju je kreirala javna vlast. Ta je moć ili (o)vlast ozakonjena pa je utemeljena u zakonu, ishodišno i Europe.

26 Što je minimalni zahtjev i Konvencije za zaštitu ljudskih prava i temeljnih sloboda Vijeća

27 Posebno sagledavajući ostvarenje prava na suđenje u razumnom roku, te uzimajući u obzir u radu iznesene podatke o prosječnom tarajanju postupka pred drugostupanjskim upravnim tijelom (2,6 godina) te na Visokom upravnom sudu RH (2,1 godina).

28 Rec (2001.) 9, od 5. rujna 2001.

29 Koprić.

30 Primjera radi, dug poreznih obveznika u 2014. godini iznosio je 51 milijardu kuna odnosno 14,95 BDP-a. Prema Rogić-Lugarić, Tereza, Čičin-Šain, Nevia, „Alternativno rješavanje sporova u poreznom pravu: utopija ili rješenje?“", Zbornik PFZ, 64, (3), 2014., str. 348. 
okvirno uređena načelom zakonitosti. No, ne treba smetnuti s uma kako je porijeklo ovoga načela u pravilu prema kojemu nema oporezivanja bez predstavljanja ,no taxation without representation “ ${ }^{31}$ Drugim riječima, o oporezivanju odlučuju predstavnici građana u predstavničkom, zakonodavnom tijelu. U ostvarenju i primjeni takvih ovlasti i prava države da nameće poreze, zakoni daju poreznim administracijama takve upravne ovlasti koje jesu i jednim dijelom i dio te vlasti ili moći oporezivanja. Upravna ovlaštenja koja su dodijeljena poreznoj administraciji omogućuju poreznoj upravi da spram poreznih obveznika u izvršavanju te vlasti nameće glavnu obvezu koja se sastoji od plaćanja poreza. U tom je odnosu javna vlast ili država u nadređenom položaju, i ne može se niti usporediti s položajem vjerovnika u jednom privatnopravnom odnosu. Ta je nadređenost ili superiornost kroz porezna proceduralna pravila posebno naglašena. Njemačka doktrina o odnosu porezne administracije i poreznog obveznika imala je utjecaja i na druge države, a iz takve doktrine proizlazi da stranke u poreznopravnom odnosu nisu ravnopravni sudionici.

Privatnopravni koncept tog odnosa doduše mijenja obilježja i narav tog odnosa i uravnotežuje ga pa se sudionici tog odnosa približavaju odnosu vjerovnika i dužnika. ${ }^{32}$ No, za razliku od privatnopravnog dužničkog odnosa u kojem vjerovnik može odustati od svojeg zahtjeva prema dužniku, čime prestaje i pravni odnos (...), državi u poreznopravnom odnosu te državi kao vjerovniku u javnodužničkom odnosu načela zakonitosti i jednakosti pred zakonom ne daju pravo odustajanja od svojeg zahtjeva nego, naprotiv, ona ima dužnost svoj zahtjev prema dužniku ne samo postaviti nego i ostvariti. ${ }^{33}$

\section{POREZNE PROMJENE U OKRUŽENJU I NJIHOVI UČINICI NA HRVATSKI POREZNOPOSTUPOVNI OKVIR - ALTERNATIVNI OBLICI SUDSKOG RJEŠAVANJA SPOROVA U PODRUČJU OPOREZIVANJA: MOGUĆI PRAVCI}

Poredbenopravno gledano, porezni sustavi europskih država u zadnjem desetljeću doživljavaju velike promjene. ${ }^{34}$ Uslijed sve većih zahvata, utemeljenih

31 Soler Roch, M., Tax administration vs. Taxpayer. A new deal?, dostupno na: http://www.eatlp.org/ uploads/public/Reports\%20Rotterdam/Moessner\%20lecture.pdf. (1. 5. 2012.).

32 O razlici javnoga i privatnoga prava, vidi Padjen, Ivan, ,Javno i privatno pravo: Transfer pravnih teorija“, Zbornik radova Pravnog fakulteta u Splitu, god. 44, 3-4/2007., str. 443-461, i Bačić, Arsen, „O engleskom "nerazumijevanju” francuskog upravnog prava i Conseil D'etata - O jednoj povijesnoj epizodi u razvoju komparativnog ustavnog i upravnog prava“, Zbornik radova Pravnog fakulteta u Splitu, god. 45., 1/2008., str. 31-47.

33 Lončarić-Horvat, O., „Zastara u poreznom pravu“, Pravo i porezi, br. 6/2003., str. 4., Prema, Žunić Kovačević, ,Europeizacija hrvatskog poreznog postupovnog prava - o dosadašnjim ne/uspjesima kroz prizmu zadanih i imperativnih promjena", Godišnjak Akademije pravnih znanosti Hrvatske, vol. V., br. 1., 2014., str. 78-91.

34 Vidi Tax reforms in EU Member States 2013, Tax policy challenges for economic growth and fiscal sustainability, EUROPEAN ECONOMY 5|2013, Economic and Financial Affairs, EK, dostupno na http:// ec.europa.eu/economy_finance/publications/european_economy/2013/ee5_en.htm (25.4. 2013.). 
u materijalnim poreznim propisima, u ekonomsku snagu poreznih obveznika i njihovu sposobnost da plate porez, mijenjaju se i postupovni okviri oporezivanja. Odnos poreznih obveznika i poreznih vlasti nastoji se utemeljiti na fairplay-konceptu, uzajamnoj suradnji pa čak i na naglašenoj dobrovoljnosti ili

voluntarizmzu. ${ }^{35}$ OECD je tijekom 2012. godine izradio studiju o modelima tzv. jače suradnje, tzv. modeli enhanced relationshsip koji, upravo dugoročno, trebaju rezultirati promjenom postojećeg odnosa u odnos poreznog obveznika i porezne vlasti koji se temelji i održava na povjerenju. ${ }^{36}$

Složenost hrvatskog poreznog sustava i njegove česte mijene sve su češći razlog posezanju poreznih obveznika za zaštitom pred upravnim ili sudskim tijelima dok je istodobno time pravna sigurnost ozbiljno ugrožena. Učestala zadiranja u slova poreznih zakona postala su gotovo praksa, a ozbiljni zahvati u prava poreznih obveznika često se dešavaju bez konzultiranja, ne samo stručnjaka, već i poreznih obveznika, kao i drugih sudionika koji imaju interesa biti uključeni u pripreme koje bi trebale prethoditi zakonodavnim intervencijama u temeljna prava poreznih obveznika. ${ }^{37}$ Prethodno prikazana učestalost poreznih sporova na upravnim sudovima jasan je pokazatelj potrebe promišljanja alternativnih oblika rješavanja poreznih sporova. ${ }^{38}$

Unatoč mogućim različitim zaključcima o učinkovitosti upravnosudskog rješavanja sprorova u području oporezivanja, opravdano je i aktualno ispitati alternative trenutnom uređenju i pristupu. Poredbena iskustva pokazuju da je pored postojećeg uređenja (i u hrvatskom) poreznom sustavu moguće promišljati više pravaca izgradnje učinkovite kontrole i nadzora uprave u poreznim stvarima. ${ }^{39}$ Govoreći o putevima i ostvarenju zaštite prava poreznih obveznika, moguće je razlikovati sudske i izvansudske modele rješavanja sporova i zaštite prava poreznih obveznika. S obzirom na temu rada, neće se razmatrati oblici rješavanja poreznih sporova koji ne predstvaljaju dio pravosudnog sustava. U tom smislu,

35 Belgija, Francuska i dr. EU-države 2013. su uvele nova pravila o dobrovoljnom prijavljivanju poreza, prema

http://www.loyensloeffnews.be/en/publications/newsflashes/private-client-newsflashes/new-ruleson-voluntary-disclosure-in-belgium-as-of-2-july-2013-abolition-of-current-voluntary-disclosure-rulesas-of-1-january-2014.html (10. 07. 2013.). Jednako, Belgija, Njemačka, Italija, Grčka, Španjolska, Portugal nalaze se među držvama koje su u određenim razdobljima ponudile poreznim obveznicima amnestiju za određene dohotke/dobiti i pod određenim pretpostavkama.

36 OECD Tax Intermediaries Study - Working Paper 6 - The Enhanced Relationship, prema http:// www.oecd.org/tax/administration/39003880.pdf (25. 04. 2012.).

37 Vidi o stvaranju poreznog zakonodavstva više u Thurony,Victor i Gordon, Richard K., ,Tax Legislative Process", u Tax law Design, International Monetary Fond, 1996. Isto, Brys, B. (2011.), „Making Fundamental Tax Reform Happen”, OECD Taxation Working Papers, No. 3, OECD Publishing. http://dx.doi.org/10.1787/5kg3h0v54g34-en

${ }^{38}$ Kod dostavljanja podataka od strane upravnih sudova, istaknuto je od strane sudaca kako je priljev poreznih predmeta osjetno veći nakon izmjena i intervencija u zakonske propise od strane zakonodavca. Dapače, u razdoblju od 2004. do 2011. godine razvidno je da je 2009. godina svojevrsna razdjelnica kada raste broj uloženih žalbi i stagnira broj riješenih žalbi, dok otada raste broj tužbi pred upravnim sudovima te neriješenih tužbi. Prema Rogić Lugarić, T., Čičin-Šain, N., op. cit.

39 Vidi detaljnije u Rogić Lugarić, T., Čičin-Šain, loc. cit. 
od moguća dva pravca kretanja u osmišljavanju učinkovite sudske pravne zaštite u poreznim stvarima: osnivanje financijskih sudova te uspostava arbitražnog pravosudnog sustava, u nastavku se razmatraju obilježja potonjeg. ${ }^{40}$

\section{USPOSTAVA ARBITRAŽNOG PRAVOSUDNOG SUSTAVA U POREZNIM PREDMETIMA - PRIMJER PORTUGALA}

Može se primijetiti da je narav tijela koja čine arbitražni pravosudni sustav nedavno raspravljana u predmetu pred Europskim sudom (dalje u tekstu: ESP). ${ }^{41}$ Naime, u predmetu C-377/13 postavilo se pitanje ${ }^{42}$ dopuštenosti iznesenog u zahtjevu za prethodnu odluku a zbog posebne prirode tijela koje je uputilo taj zahtjev. ${ }^{43}$ Pitanje je bilo može li se Tribunal Arbitral Tributário - porezni arbitražni sud - smatrati „,sudom države članice“ u smislu članka 267. UFEU-a. ${ }^{44}$ U tom kontekstu treba posebno ukazati na ustaljenu sudsku praksu Suda, sukladno kojoj arbitražni sudovi osnovani na temelju ugovora nisu „sudovi države članice“ u smislu članka 267. UFEU-a, jer Sud nije nadležan odlučivati o prethodnim pitanjima koja su mu takvi sudovi uputili.

Odgovori na navedena, ali i na druga pitanja, od šireg su značaja, pa se u nastavku daje prikaz iznesenih stavova u odgovoru na neka od postavljenih pitanja budući da bismo mogli, na primjeru portugalskog rješenja statusa navedenih tijela, utemeljiti i zaključak o općim osobinama i o naravi takvog sustava rješavanja poreznih predmeta te provedbe sudske kontrole u poreznim stvarima.

Navedena arbitraža definirana je kao ,alternativni oblik sudskog rješavanja sporova u području oporezivanja, pri čemu arbitraža može obuhvaćati razne vrste sporova između poreznih obveznika i poreznih tijela. Posebnim su propisom uređeni opseg nadležnosti, način osnivanja i rad arbitražnih sudova u poreznim predmetima kao i učinci njihovih odluka i pravnih lijekova podnesenih na te odluke. Međutim, porezni arbitražni sud nije dio temeljnog sustava redovnih i upravnih sudova u Portugalu, već predstavlja, sukladno zakonskom izričaju, „alternativni oblik sudskog rješavanja sporova u području oporezivanja“ “. ${ }^{45}$ Takav se alternativni oblik rješavanja sporova temelji na primjeni posebnih arbitražnih

40 I danas aktualna promišljanja o uspostavi financijskih sudova, što bi moglo predstavljati promjenu postojećeg uređenja, kroz „dokidanje“ drugostupanjskog upravnog postupka, dio su problematike koja se $\mathrm{u}$ radu ne obrađuje.

41 Predmet C-377/13, Ascendi Beiras Litoral e Alta, Auto Estradas das Beiras Litoral e Alta, SA protiv Autoridade Tributária e Aduaneira, presuda objavljena OJ C 282, 25. 8. 2014., p. 16-16.

42 Pored pitanja koje se odnosilo na mogućnost da portugalski zakonodavac ponovno uvede posebne pristojbe na transakcije povećanja temeljnog kapitala društava kapitala.

43 U svom mišljenju, prijedlogu odluke, nezavisni odvjetnik, baveći se pitanjem nadležnosti Suda za davanje odgovora na prethodno pitanje, iznosi bitne elemente prosudbe naravi takvog tijela. Vidi mišljenje Macieja Szpunara, izneseno 8. travnja 2014., dostupno na, http://eur-lex.europa.eu/legal-content/HR/ TXT/?uri=CELEX:62013CC0377., Mišljenje: ECLI:EU:C:2014:246.

44 Ugovor o funkcioniranju EU, dostupno na, http://eur-lex.europa.eu/legal-content/EN/ TXT/?uri=uriserv: OJ.C_.2010.083.01.0001.01.ENG\#C_2010083EN.01004701 (dalje u tekstu: UFEU).

45 Zakonom br. 3-B/2010. 
tehnika za rješavanje sporova između poreznog obveznika i poreznog tijela.

U razmatranju posebne naravi i kvalifikacije arbitražnih poreznih sudova važno je skrenuti pozornost na samo korištenje pojma ,arbitraža“ ili „arbitar“ u nazivu tijela koje ne mora značiti da se radi o arbitražnom sudu u užem smislu riječi. Pojedina tijela u državama članicama EU koja su nadležna za rješavanje sporova u svom radu primjenjuju postupovna pravila karakteristična za arbitražne sudove te mogu predstavljati arbitražna tijela, ali pri tome se radi o arbitraži u širem smislu. Takvu vrstu arbitraže treba razlikovati od arbitraže u užem smislu: ona se temelji na kompetencijama i volji stranaka da povjere rješavanje spora nedržavnom - privatnom sudu. ${ }^{46}$ Navedena je razlika od velikog značenja za ispravnu kvalifikaciju poreznih arbitražnih tijela, sudova iz članka 267. UFEU-a.

Iz prakse Suda proizlazi da samo tijela država članica ili subjekti kojima su države povjerile obavljanje zadaća u području pravne zaštite mogu upućivati Sudu zahtjeve za prethodnu odluku jer su same države odgovorne za primjenu i poštovanje prava Unije na svom državnom području. Stoga se smatra da arbitražni sudovi u užem smislu riječi, shvaćeni restriktivno, nisu stricto sensu ni tijela država članica ni subjekti koji u ime tih država obavljaju zadaće u području pravne zaštite već su prije svega i po naravi privatne ustanove ili tijela. Naime, bit arbitraže stricto sensu leži u njezinoj nedržavnoj naravi, točnije u nejavnoj prirodi. Arbitražni su sudovi u pravilu privatni sudovi kojima je povjereno, umjesto nacionalnih (državnih i javnih) sudova, rješavanje sporova. Povjeravanje predmeta arbitražnom sudu pretpostavlja odricanje stranaka od prava podnošenja predmeta na odlučivanje državnom sudu, te podredno na pravnu zaštitu koju pruža država. ${ }^{47}$ Dakako, povjeravanje spora u nadležnost arbitražnog suda temelji se na propisima kojima je uređeno kakve vrste sporova mogu biti povjerene arbitraži, no u pravilu su to privatnopravni sporovi.

ESP, tumačeći pojam „suda države članice“, dopušta zahtjeve za prethodnu odluku koje upućuju arbitražna tijela javnog prava. ${ }^{48}$ Kod razmatranja naravi poreznih arbitražnih sudova, na primjeru portugalskoga prava, jasno je da takvi sudovi nisu osnovani na temelju sporazuma stranaka, već se osnivaju temeljem propisa. Alternativnost kao obilježje poreznih arbitražnih sudova proizlazi iz toga što tužitelji, najčešće porezni obveznici, imaju mogućnost izabrati arbitražu ili upravni sud. Navedeno je pravo predviđeno i uređeno propisima, dostupno svakom poreznom obvezniku u sporovima predviđenima propisom..$^{49} \mathrm{U}$ prilog

46 U predmetu Nordsee, Sud je isključio mogućnost upućivanja zahtjeva za prethodnu odluku arbitražnim sudovima osnovanima na temelju ugovora stranaka jer arbitra nije smatrao „sudom države članice", a zbog njegove vrlo slabe veze sa zakonskim sustavom sudske zaštite u državama članicama. Takva je sudska praksa kasnije potvrđena u većem broju presuda, npr. presuda Eco Swiss, C-126/97, EU:C:1999:269, t. 34., Presuda Denuit i Cordenier, C-125/04, EU:C:2005:69, t. 13., i dr.

${ }^{47} \mathrm{O}$ prirodi sudske arbitraže, v. Uzelac, Alan, Nove granice arbitrabilnosti prema Zakonu o arbitraži, dostupno na, www.alanuzelac.from.hr\%2FPdf $\% 2$ Fnove_granice_arbitrabilnosti.pdf.

48 Vidi presudu Handels- og Kontorfunktionærernes Forbund i Danmark, 109/88, EU:C:1989:383, t. 7.-9., Rješenje Merck Canada, C-555/13, t. 15.-25., EU:C:2014:92.

49 Dakle, ne ovisi o prethodnom izražavanju volje stranaka da sporove povjere arbitraži. 
stavu da porezni arbitražni sud nije arbitražni sud stricto sensu govori posebno i sama priroda pravnih odnosa za koje je taj sud nadležan - poreznopravnih odnosa. Za razliku od privatnopravnih odnosa, takvi odnosi nastaju, mijenjaju se i prestaju neovisno o volji stranaka u tom odnosu. Sadržaj tih odnosa ne proizlazi iz autonomije volje stranaka, već je određen isključivo propisom. Dakle, cijelo poreznopravno područje nije po svojoj prirodi arbitrabilno na način na koji ,arbitražnost“ dopušta povjeriti sporove na rješavanje sudu ili tijelu koje je osnovano voljom stranaka. Konačno, javnopravnost ovoga područja posebno je naglašena kroz činjenicu da je u poreznim stvarima jedna od stranaka uvijek javnopravno tijelo - državno tijelo koje nastupa u okviru svoje nadležnosti kao nositelj vlasti i obavljanja funkcije vlasti: utvrđivanje i naplata poreza, kao isključivog prava države. Navedena i naglašena javnopravnost odnosa i područja posebno upućuje na to da tijelo nadležno za rješavanje sporova u tom području, kao što je porezni arbitražni sud, nije moguće kvalificirati kao privatni sud.

Ipak, za klasifikaciju tog tijela kao suda države članice u smislu članka 267. UFEU-a valjalo je ispitati jesu li ispunjeni i drugi uvjeti koji proizlaze iz sudske prakse.$^{50}$ Naime, u iznesenom primjeru portugalskih poreznih arbitražnih sudova utvrđeno je da takvi sudovi primjenjuju niz tehnika, metoda te pravila postupka karakterističnih za arbitražne sudove te su se time udaljili od načela funkcioniranja „tradicionalnih“ javnih sudova. Takva postupanja motivirana su efikasnošću ekonomskom i vremenskom: osigurati rješavanje spora u kraćem vremenu, po najnižoj mogućoj cijeni jer tako, nesumnjivo, predstavljaju alternativu upravnim sudovima. Za ispravnu kvalifikaciju poreznih arbitražnih sudova, od značaja su i pravni temelj funkcioniranja tijela te njegova trajna narav. Da bi se porezni arbitražni sud kvalificirao kao sud države, u skladu s ustaljenom sudskom praksom, zahtjev za prethodnu odluku može uputiti samo stalno tijelo osnovano na temelju prava države članice. Arbitraža u poreznim predmetima mora se temeljiti na zakonskoj normi koja uspostavlja stalni ili trajni sustav arbitraže (u poreznim stvarima) te definira načela i pravila njezinog rada. Sam sastav suda određuje se, u pravilu, posebno u svakom predmetu i na zahtjev zainteresiranog poreznog obveznika, ali takav zahtjev - pravo poreznog obveznika da zatraži osnivanje arbitražnog suda i način određivanja njegovih članova proizlazi iz zakonske norme. Iako je konkretni sastav suda određen samo za potrebe jednog predmeta, ipak je riječ o različitim sastavima suda u pojedinim predmetima. Takav sud nije ad hoc sud, dio je sustava za rješavanje sporova te se može tvrditi da, promatrano u cjelini, ima trajnu narav.

Obvezna nadležnost tijela također je važan element kvalifikacije poreznih arbitražnih sudova, posebno jer je još jedno načelo iz sudske prakse Suda neophodno za klasifikaciju tijela kao suda države članice u smislu članka 267. UFEU-a. Naime, Sud smatra da povjeravanje spora na rješavanje tijelu koje je uputilo zahtjev za prethodnu odluku treba za stranke biti obvezno, a ne proizlaziti

50 To posebno u odnosu na elemente funkcioniranja takvog tijela u kojima su primjenjivane tehnike karakteristične za arbitražne sudove. 
isključivo iz njihove volje, što je slučaj arbitražnih sudova stricto sensu. Kako su porezni arbitražni sudovi dio sustava alternativnog rješavanja sporova u poreznim predmetima, to porezni obveznik koji spor s poreznim vlastima želi povjeriti na sudsko rješavanje ima izbor između obraćanja upravnom sudu ili traženja osnivanja arbitražnog suda za porezne predmete. Pri tome, porezno tijelo mora postupiti sukladno odluci poreznog obveznika. Iako se nadležnost poreznih arbitražnih sudova ne može smatrati obveznom za stranke (porezni obveznik, stranka, ne mora podnijeti spor tom tijelu, nego se može obratiti upravnom sudu), posljedica tužiteljeva upućivanja predmeta nadležnom sudu jest činjenica da tuženik ne može uspješno osporiti tu nadležnost. Pri tome, to pravo poreznog obveznika da odabere način rješavanja spora ne proizlazi iz njegove vlastite inicijative, nego iz volje zakonodavca koji je stvorio dva paralelna sustava rješavanja sporova s poreznim vlastima. Nijedan od tih sustava nije pojedinačno obvezan, već porezni obveznik, ako želi svoj spor s poreznim tijelom uputiti sudu na rješavanje, mora odabrati jedan od njih. Pri tome je portugalski zakonodavac propisao da podnošenje zahtjeva za osnivanje arbitražnog suda isključuje pravo istim argumentima pobijati odluku poreznog tijela pred upravnim sudom te da je arbitražna odluka o meritumu obvezujuća za porezne vlasti. Prema tomu, porezna arbitraža nije puko dodatno pravno sredstvo kojim raspolaže porezni obveznik, nego stvarna alternativa tradicionalnom pravosudnom sustavu. U tom smislu, pretpostavka obvezne nadležnosti tijela koje upućuje zahtjev mogla se smatrati ispunjenom u navedenom primjeru.

Pretpostavka kontradiktornosti postupka i primjene prava pred poreznim arbitražnim sudovima od velikog je značaja, kako za porezne obveznike, tako i za porezne vlasti. Propisujući načela postupka pred arbitražnim sudovima u poreznim predmetima posebice se osiguravaju kontradiktorni karakter tog postupka i ravnopravnost stranaka. Značaj tih načela potvrđen je kroz normu koja predviđa povredu tih načela kao osnovu za podnošenje žalbe upravnom sudu protiv arbitražne odluke. Arbitražni sudovi u poreznim predmetima sude na osnovi zakona te je isključeno odlučivanje na načelu pravednosti, a takvo je uređenje i jedino moguće i ispravno budući da je zadaća poreznih arbitražnih sudova upravo i posebice ocjena poreznih akata s gledišta zakonitosti.

Pretpostavka neovisnosti poreznih arbitražnih sudova treba se razmatrati s dvaju aspekata. Prvi, vanjski aspekt govori o neovisnosti tijela i njegovih članova o trećim osobama i institucijama koje nisu povezane sa sporom, poput izvršne vlasti, viših tijela itd. Drugi, unutarnji aspekt odnosi se na članove tijela i njihovu nepristranost u odnosu na stranke u sporu te nepostojanje sukoba interesa. Porezni arbitražni sudovi nisu dio porezne uprave i drugih institucija izvršne vlasti, već predstavljaju u pravilu element sudbene vlasti. Takvi sudovi trebaju biti neovisni u odlučivanju, te imaju obvezu postupati u skladu sa zakonom i sudskom praksom upravnih sudova, dok su njihove odluke u načelu konačne i ovršne.

Porezni arbitražni sudovi sude u sastavu od jednog arbitra ili troje arbitara. Način određivanja arbitara i etičkih, deontoloških pravila koja ih obvezuju uređuju se zakonskim normama. Iako arbitri nisu profesionalni suci, jamstvo njihove 
osobne neovisnosti ima osnove različite od onog u slučaju sudaca. Ovdje je teško govoriti o mandatu, s obzirom na to da su arbitri određeni za konkretan predmet, pa po okončanju njihova uloga završava. Neovisnost arbitara proizlazi iz činjenice da je riječ o osobama samostalnog položaja, kojima funkcija arbitra nije glavna profesionalna djelatnost, dok je pravni okvir koji uređuje nepristranosti arbitara i njihovu neovisnosti o strankama sličan onom koji se primjenjuju u odnosu na profesionalne suce.

Cilj postupka pred poreznim arbitražnim sudovima nije sklapanje sporazuma između stranaka, a donesena odluka nema karakter neobvezujuće preporuke ili mišljenja. Ta značajka jasno razlikuje taj sud od miritelja i drugih sličnih subjekata, osoba ili institucija koje postupaju u okviru drugih alternativnih načina rješavanja sporova, posebno u obliku pregovora ili mirenja. ${ }^{51}$

\section{UMJESTO ZAKLJUČKA}

Sudska kontrola segmenta izvršne vlasti i uprave koji se tiču oporezivanja te jamstvo sudske zašitite u poreznim stvarima jedan su od temelja vladavine prava i pravne sigurnosti. Jačanje sustava zaštite prava poreznih obveznika važan je segment razvoja pravne države, a istodobno, riječ je i o neophodnom segmentu reforme hrvatske javne uprave. Danas se nameće imperativ pojednostavljenja poreznog postupka i njegove jasne i precizne nomotehničke uređenosti $\mathrm{u}$ zakonskim rješenjima s naglašenom sudskom zaštitom u okviru upravnog spora i to spora pune jurisdikcije. Jednako je potrebno razmisliti o razinama odlučivanja u provedbi kontrole u poreznim stvarima kako bi se izgradio učinkoviti sustav kontrole u poreznim stvarima. Očita, u radu prikazana preopterećenost drugostupanjskih upravnih tijela te upravnih sudova može biti jedan od razloga traženja alternativnih puteva rješavanja sporova u poreznom pravu. Iako narav i obilježja pravnih odnosa koji nastaju u poreznom pravu dopuštaju određeno odstupanje od naglašenog javnopravnog obilježja u svim segmentima uređenja poreznoga prava, noviji oblici ili instrumenti rješavanja poreznih sporova i provedbe kontrole u poreznim stvarima trebaju to obilježje zadržati. Stoga se porezni arbitražni sudovi, kao element pravosudnog sustava ravnopravan s upravnim sudovima, čine zadovoljavajućim rješenjem. Specifičnost takvih tijela jest u činjenici da su se zakonodavci pojedinih država odlučili dati poreznim obveznicima mogućnost povjeravanja svojih sporova s poreznim tijelima na rješavanje sudu koji je manje formalan, brži i jeftiniji od običnih upravnih sudova. Riječ je o šire prisutnom trendu smanjenja formaliziranosti i pojednostavljenja sudskih postupaka jednim dijelom pomoću tehnika i alata svojstvenih privatnopravnom području i mehanizmu rješavanja sporova. Izgradnju ovakvih instrumenata moguće je tumačiti i kao primjer specijalizacije sudova i sudaca, neophodne u kontekstu sve veće složenosti socioekonomskih odnosa, a time i sporova podnesenih sudovima na rješavanje. No, kako je u literaturi istaknuto 
da je sve teže govoriti o sadržajnoj razlici između uprave i sudstva, uslijed čega se sve više prihvaća shvaćanje o razlici samo formalno organizacijske prirode, to javnopravna narav može biti dostatno početno obilježje instumentarija čije se ustrojavanje predlaže. Na tragu navedenoga čini se važnim pitanje radi li se kod uvođenja novih i alternativnih mehanizama kontrole u poreznim stvarima zapravo o ,postmodernističkom pristupu pravdi koji proizlazi iz evolucije pravosudnog sustava i pravnog sustava u cjelini“", što je mišljenje nezavisnog odvjetnika u, u radu, iznesenom primjeru. Dakako da se na evoluciju ne možemo oglušiti, no na teoretičarima je upravnog i poreznog prava da, u svojim analizama reformi i prijedloga prilagodbe i izgradnje pravne regulative i prakse, ne zanemare ideal pravne države.

\section{ADMINISTRATIVE COURT CONTROL IN TAXATION MATTERS}

Starting with the current organisation of administrative court control in taxation matters, this paper, after a brief overview of the normative legal framework of control in such matters, provides an analysis of certain indicators of administrative and administrative court control implementation in taxation matters. The experience of the application of administrative control in taxation matters and an analysis of accessible indicators of recent administrative court control in taxation matters has triggered the search for new solutions for more effective protection of taxpayers' rights and for achieving the tasks of taxation bodies. Occurring changes to taxation systems also affect the Croatian taxation legal framework. Therefore, this paper considers the possible directions of development and the organisation of alternative forms for dispute resolution in the area of taxation. This overview of possible control mechanism directions in taxation law includes an arbitration judicial system for taxation matters. The context for the appearance of alternative forms of dispute resolution in taxation matters poses the question of whether changes to the implementation of control in taxation matters is of an evolutionary nature.

Key words: administrative court control, taxation matters, administrative dispute, alternative forms of dispute resolution in taxation matters, arbitration judicial system 